\title{
The Effect of Using a Learning JOURNAL in Teaching Semantics on the Tertiary Level Juniors' Achievements*
}

\author{
Ghayda Ali Muhammad \\ University of Zakho \\ M.A. in Linguistics/Cross-cultural Pragmatics \\ Higher Dip. (M.A.) in Translation
}

\begin{abstract}
This research-paper was dedicated to investigate the effects of using a largely learner-centered approach (namely a learning JOURNAL) to teach semantics to tertiary level juniors.

An experiment was designed to involve the juniorlearners at the Department of English-School of Languages-faculty of Humanities-University of Zakho as a research-sample during the academic-year 20142015.
\end{abstract}

The experimental design was based on dividing the research-sample into 2 groups; (experimental group) and (control group). The same approach in instruction was almost wholly used with both groups except that the experimental group learners, after every assignment's representation made in the classroom, were asked to write down, whatever ideas elicited from the presentation, in a journal technically called by the study as a Learning JOURNAL. One of the aims of the study was to find out if the learners could develop learner-led syllabus by means of writing in the presumed Learning JOURNA, as well as to find out whether using such a JOURNAL would have an effect on the learners' achievements in both, the formal tests and the summative tests. Then, in order to measure, on part of the learners, the benefits, the said approach in teaching semantics, a questionnaire was designed to get feedback from the learners.

Finally, the study arrived at a variety of findings, which all mostly poured to the benefit of using the Learning JOURNAL as a tool in teaching, whether in the learners' achievements or in the instruction process; all manifested by improvement in the achievements of the experimental group and its members' ability to develop a learner-led syllabus to be sued as major reference in reviews for examination.

Key terms: Authentic assessment, Cognitive-code, Explicit teaching, Implicit learning, Learner-centered teaching, Learning-JOURNAL, Learner-led syllabus, Learning-semantics competence, Semantics, Task-based language-teaching, Quasi-experimental research

\footnotetext{
* The paper has been presented in the 4th International Scientific Conference of University of Human Development- Iraq, April, 2017.
}

\section{1- Introduction}

"Listeners and readers have the task of guessing what the sender of an utterance intends to communicate."

(Patrick Griffiths 2006: p.21)

Well, if listeners, readers, and speakers, since as early as Adam and Eve existed on Earth till the moment, all have been lively used to guess, in appropriate ways, the meaning of what the sender intends to communicate, then:

Why should a community of an EFL tertiary level as whole, whether pedagogues or learners, have perturbations about 'semantics' as a concept, or as a study-subject in the classroom?

The above-brought-up question is an exceptionally important one, for it doubtlessly requires a fullysatisfying answer.

But, before trying to answer the said-question, a very important fact should be acknowledged; pedagogues on their part should frankly acknowledge that their own perturbations, about the matter, inevitably come as a result of their students' ones.

- Why is that?

- In order to explain such a why, first of all, light should be cast on the nature and concept of semantics.

In theory, semantics is a descriptive sub-discipline of linguistics, which is neither essentially concerned with the way words came in history to obtain the meanings they refer to, nor its job is to give comprehensive accounts of the knowledge of man, but it

"... is the study of context-independent knowledge that users of a language have of word and sentence meaning. The meanings of constructions are compositionally assembled out of the meanings of smaller units and what comes into the scope of which operations can influence the meaning of a construction." (Griffiths 2006: p.21).

If the above account of the field of semantics is seriously taken for granted, then, both pedagogues and learners would have the right to worry and have perturbations about the matter. Simply, because semantics is a study-worthy concern, and 'study' means working so hard to uncover the mystery of meaning, which has been involving the minds of philosophers and thinkers since Plato and Aristotle till now.

Hence, this study is an attempt to examine whether semantics as both, a linguistic concept and as a studysubject in the classroom, is somehow teachable, 
approachable and comprehendible by applying certain cognitive-based teaching methods to students who have perturbations about such an important matter.

No doubt, on part of the students, it could be very easy to them to memorize dozens of definitions of the concept of semantics, which can be summarized in such a very short sentence like 'It is the meaning of meaning' or so, but still, it could be too ambiguous to them how to identify the approaches to meaning in very complicated situations, especially when they have to differentiate between explicit (denotative) and implicit (connotative or metaphoric) meaning of a word or expression, or what is the relative effect of an implicit meaning of a word, or what are the relative effects of eliciting a certain meaning from a word, or a phrase, or a sentence. Furthermore, pedagogically speaking, it is also very important to discover in what way the explicit teaching or the implicit learning, could be more appropriate for the student to conceptually comprehend the meaning of things and concepts.

Hence, selecting an approach to the teaching of such an important sub-discipline like semantics is still a challenge to the linguistics-teaching communities. This is, and due to its cognitive and philosophical nature, teaching semantics still much perturbs the minds of both, the pedagogue and the learner. Therefore, in order to stand alert and know where they stand for the challenge, the teachers of semantics should be as innovative as an initiator, i.e., making use of all the approaches of teaching available in the field, in order to realize both, the lesson's general and specific objectives.

For instance, one of the available-tools of TEFL is the use of a PORTFOLIO on part of the pedagogues, and a learning JOURNAL on part of both learners and pedagogues, to document the students' achievements for assessment. But, it most-likely happened that when the pedagogue proposes the JOURNAL as a project whereby the learners' ability to learn could be developed and improved as an implicit learning, the reaction on part of the learners would come asking:

- Why should the project of a JOURNAL be considered as a testimony of my learning?

or ....

- The JOURNAL is too much work to do. Does it deserve my time and efforts since the teacher can assess my performance in shorter methods?

(Light, Chen, and Ittelson 2012: p. 72)

Finally, in order to carry out an authentic assessment of the students' performance in semantics as a studysubject, borrowing from different methods of TEFL such as the 'learner-centered', 'learner-led', 'task-based', the explicit teaching and 'cognitive-code' methods, this study has made a eclectic approach for the teaching of 'semantics.

\section{2- The Problem}

Most of the EFL learners at the tertiary level have opaque knowledge, or sometimes they even have misconceptions, about the term semantics. This is, particularly, when the pedagogue comes to measure the learners attitudes and emotional reactions to words and concepts (Johnson \& Johnson 1999: p. 386), or when the learners encounter difficulties of how the meaning in a language is structured, whether on word, or phrase, or sentence level, and how to differentiate between several types of meanings and how utterances communicate the meanings. Hence, so many problems may be faced in the teaching-learning process of semantics, which sometimes may make the situation much more sophisticated and problematic, and in most of the cases matters stay unsolved, and then would be taken just like that!

\section{3- Aims}

Semantics is the application of linguistic theory to meaning. Hence, this quasi-experimental-study aims at:

* Firstly, discovering how far certain educational methods could positively affect the development of the learners' comprehension in the study of meaning.

* Secondly, attempting, through a practical combination of learner-centered, task-based, learnerled, explicit-teaching-based, and cognitive-code approaches, to investigate the students' ability to take the responsibility of:

- How to comprehend the meaning of semantics as a concept,

- How to train themselves, through writing down their reflections about their weekly study, in a learning JOURNAL, on how to understand the variables related to 'semantics' as a subject, i.e., variables such as meaning relations, metaphoric meaning, multiple meaning, lexicalization, component of meaning, semantics and dictionary, semantic features, componential analysis, etc., and the reflection of such an experience on their results in the formal-test (semester-test),

* Thirdly, discovering whether the learners have the ability, in the course of the experiment, to develop a 'learner-led syllabus' from the materials written down in the said learning JOURNAL after each assignmentrepresentation lesson, in order to be adopted as the major reference for the learners in the following summative-test, and then to check its effects on the learners results in the academic-year's finalexamination, and

* Fourthly, at the end of the academic-year, investigating the learners' reflections on such an experience of using a learning JOURNAL as a reliable self-developed-syllabus to be used as a reference for the formative and summative tests.

\section{4- Significance}

The value of the study lies in the feasibility of adapting cognitively-based approaches, to develop learning JOURNAL by the students, in teaching semantics at the tertiary level in general. The study may draw the attention of two types of concerned people; the attentive researchers and the thinking teachers, who 
both would find the results of this study of a great help to develop further studies in this field or seek new approaches to teaching semantics, especially in respect of enhancing the disposition of using the learnercentered approaches in TEFL.

\section{5- Limits}

The study is limited:

- (in subject) to the approaches of teaching semantics to the tertiary level's EFL learners, and

- (in stage) to the juniors of the academic-year 20142015 at the Department of English (DoE for short)/ School of Languages (henceforth SoL)/Faculty of Humanities (henceforth FoH)/University of Zakho (henceforth UoZ).

\section{6- Hypotheses}

In order to develop fruitful conceptions about the development of the learners' 'learning-semantics competence', it is hypothesized that:

1- Using learning JOURNAL, on the part of group (A), in teaching-learning semantics, no significant differences would be expected in the formative test results between group (A) and group (B) achievements."

2- Using learning JOURNAL, on the part of group (A), in teaching-learning semantics, significant differences are expected as a gradual weekly development in group (A)'s achievements."

3- Using learning JOURNAL, on the part of group (A), in teaching semantics, no significant differences would be expected between group (A) and Group (B) achievements in the summative tests.

4- The students of semantics have the ability to develop a learner-led syllabus, based on materials written in a learning JOURNAL to use it as a unique reference to improve their achievements in both, the formative-test and the summative-test.

\section{7- Related Literature}

It is true that philosophers and thinkers, for thousands of years, have carefully and seriously questioned the meaning of meaning, but the speculations about meaning, until the emergence of semantics, as a subdiscipline within the context of the linguistic studies, were in the beginning brought-up during the late $19^{\text {th }}$ century as preliminary notions. For instance, it was seen by Bréal "as an emerging science opposed to phonetics" (Mathews 2007: p. 361). The same conception mostly continued to dominate during the early decades of the $20^{\text {th }}$ century, when during the 1930s Bloomfield argued that "..., it was a field of covering both grammar as one account of meaning forms, and the lexicon" (ibid: p. 361). It stayed seen narrowly even during the 1960 s as "the study of meaning in the lexicon alone" (ibid: p.361).

In the study of meaning, attempts continued, during the $20^{\text {th }}$ century, to identify the area where semantics appeared as "an independent discipline of study, although some scholars restricted semantics to the study of meaning in "....opposition to pragmatics, [while] others included pragmatics as one of its branches." (ibid: p.361). As an example of the viewing which went-to-extremes in specifying the role of semantics, some scholars confined its scope in practice very narrowly, when in the mid-1990s some proponents of the 'contemporary semantic theory' deal only with matters related to "formal semantics and neglecting the meaning of lexical units." (ibid: p.361). But, on the other hand, such narrowing, of the role of the semantics field, did not stop the emergence of semantics' subfields such as:

- 'Lexical semantics' to deal with the meaning of words and the relationships between the meaning of words; and

'Phrasal semantics' (or sentential semantics), which deals with the meaning of linguistic units larger than the word

(Fromkin, Rodman \& Hayms (2003: p. 173).

Furthermore, different definitions took place by researchers and scholars to explain semantics as a concept and as a sub-discipline, in the context of the linguistic studies. Although most of these definitions might differ in some minimum details, they all have given a common view of this area of linguistic studies.

Saeed's (2000: p. 3) definition came as follow: "Semantics is the study of meaning communicated through language." Sebastian Lobner (2002: p. 2) put it in a very short sentence: "Semantics is the part of linguistics that is concerned with meaning." Fromkin, Rodman \& Hayms (2003: p. 173) put it this way: "The study of the linguistic meaning of morphemes, words, phrases, and sentences is called semantics." Adding further details to the definition, Goddard (2007: p. 1) argued that: "Semantics, the study of meaning, stands at the very center of the linguistic quest to understand the nature of language and human language abilities."

Meanwhile, because the connection between semantics and pragmatics is so tight that a distinction could hardly be made between the two fields as subdisciplines of linguistics, which some scholars explained it as an overlap between the two fields, while others, Aitcheson for instance, gave pragmatics a very subordinate status saying that "it is the wastebasket of semantics", whereas Campbell and O 'Pourke David Shier put the distinction between the two fields as a matter of information associated with an utterance of a sentence, then:

Semantic information is encoded in the sentence; pragmatic information is generated by, or at least made relevant by, the act of uttering the sentence. ( $\mathrm{O}$ 'Pourke David Shier 2002: p.284)

Hence, as pragmatics seemed to deal with the interaction of semantic knowledge with men's knowledge of the surroundings, taking into 
consideration contexts of language use, so, as putting it in contrast with pragmatics, Griffths wrote that:

Semantics is the study of the 'toolkit' for meaning knowledge, encoded in the vocabulary of the language and in its patterns, for building more elaborate meanings, up to the level of sentence meanings

(Griffths 2006: p.1)

As putting it also into the same context, i.e., in contrast with pragmatics, Kearns defined it saying:

Semantics deals with the literal meaning of words and the meaning of the way they are combined, which are taken together from the core meaning, or the starting point from which the whole meaning of a particular utterance is constructed. (Kearns 2011: p.1)

semantics is:

Finally, David did not suffice to say that

A major branch of LINGUISTICS devoted to the study of MEANING in LANGUAGE.

But he added a further touch saying:

... philosophical semantics examines the relations between linguistic expressions and the phenomena in the world to which they refer, and considers the conditions under which they can be said to be true or false. (Crystal 2012: p.428)

However, as "Meaningfulness, or semanticity, is generally taken to be one of the defining properties of language" (Lyons 1996: p.12), and in order to describe the semantic knowledge comprehensively, scholars and researchers have been writing on a variety of topics and using very different approaches to respond to inquiries concerning the field. Furthermore, in order to emphasize the core role of semantics in the development of linguistic studies, theories differ on details of the relationship between semantics and other levels of analysis like syntax and morphology, but, however, "all seem to agree that linguistic analysis is incomplete without semantics." (Saeed 2000: p. 7).

Consequently, as we mentioned above, since Plato and Aristotle up to the present time, so many philosophical theories emerged to deal and tackle the difficulties encountered in the course of answering the vital questions about the nature and role of semantics. Some of these theories are outstanding, while others are less well-known. In his LINGUISTICS SEMANTICS: An Introduction, John Lyons mentioned several semantic theories among others:

- Referential (or Denotational) theory: following reference to know the meaning,

- Ideational (or Mentalistic) theory: following an idea or a concept to identify the meaning,

- Behaviorist theory: a stimulus evokes the meaning,

- Meaning-in-use theory: the use in the language determines the meaning,

- Varificationist theory: meaning is determined by the verifiability of the sentence, and
- Truth Conditional theory: meaning contributes to the truth condition.

(Lyons 1996: p.40)

Unfortunately, there is neither enough room nor intention in the small space of this study to push, from among the above-mentioned plethora of definitions of semantics, one over another, or to push a semantic theory over another, but only to show how complicated and sophisticated it could be for the learner's 'semantic competence' to comprehend such encyclopedic details given in the definitions.

Pedagogically speaking, nowadays there is a considerably growing literature on various semantic topics, which they have been everlasting branching as sub-ways to meaning. But, there is still relatively less literature written on what in terms of this study called the 'learning-semantics competence', which makes the students aware of the relationships that connect the words to each other obvious how cognitively acquire this competence, and its development through study. On the other hand, in many contexts of TEFL and TESL, curriculum matters and materials developed during the recent decade to include issues about the 'semantic competence' in analogy with other language learning competences such as the 'grammar competence', 'pragmatic competence', etc.

In order to develop a 'learning-semantics competence', N. Dittmar argued that the learner needs:

- to communicate in order to get access to the content of words and grammatical meaning,

- to learn expressions for semantic concepts like time, modality, quality, etc,

- stabilize the expressibility of basic communicative functions.

(Dittmar-cited in Spolsky ed. 1999: p. 587)

Dittmar also argued that the acquisition of semantics as a concept comes next to the application of verbal knowledge in 'real' interaction. In earlier studies, the acquisition of meaning was explained in details for First Language Acquisition (FLA) in (Clark \& Clark 1997: 407-514; Wode 1988: 134-78, 217-25-cited in Spolsky 1999: p. 587). Building on this, Dittmar made a comparison on semantic competence acquisition between the FL speakers and the SL speakers.

For the FL speakers, Dittmar argued, that in developing their knowledge in the semantic field, the meaning components of words (shape, color, form, quality quantity, etc.) are acquired to set cognitive boundaries and contrasts between them. Meanwhile, as for the SL speakers' acquisition of what we called it before the 'learning-semantics competence', it seems that the learners acquire some structures before others because of processing rules related to SLA, and thus, they pass through a medium where they can organize a semantic coherence in spoken patterns by ways of information processing (Skiba and Dittmar 1992- cited in Spolsky ed. 1999: p.589).

Furthermore, in respect of how the 'learningsemantics competence' is developed via SLA, studies have varied. Some focused on the acquisition of verbal 
means to represent semantic field, others preferred a cognitive approach to meaning. But, generally, the following mapping was taken into account:

* Focus on 'Interlanguage': The description of learner varieties 'outside the classroom' with a focus on 'learning under natural conditions' of communication (Klein and Dittmar 1979 - cited in Spolsky ed. p. 587).

* Form versus function: Words and forms are not 'autonomous' as some linguists seem to suggest, but they have communicative functions (Pfaff 1987- cited in Polsky 1999: p.588).

* Bilingual Lexicon: Varying from the FL speakers, the SLL add to the representation of the object concept a phonological variant which leads to the object concept in the SL. (Hatch 1983: 64-74- cited in Spolsky ed. 1999: p. 588).

* Operating principles: There is evidence that semantic insecurity (caused by the competition of two different words) impedes the process of grammaticalization, and thus, the passage from the 'pragmatic mode' to the 'syntactic mode' seems to be 'operated' by semantic strategies (Skiba and Dittmar 1992- cited in Spolsky ed. 1999: p. 588).

* Semantic concepts which include:

(1) Temporality which indicates the referential areas of 'time' and 'space' as very basic domains to the learner's success or failure, manifested at the elementary, intermediate, and advanced level of the learner's proficiency (Bahardwaj, Dietrich, and Noyau 1988- cited in Spolsky ed. 1999: p. 589),

(2) Special relations refer to how 'spatial meaning' is organized by the learners who fall into two groups with respect to 'reference locomotion', one of them applies a number of verbs of locomotion at the earliest stage of acquisition, while the other starts with one form which is not systematically realized in all appropriate contexts (Becker, Carroll, and Kelly 1988- cited in Spolsky 1999: p. 590).

But, significantly, it is worth mentioning that both, teachers and learners, always intend (almost consciously on part of the teachers and almost unconsciously on part of the students) to find systematic ways to involve in the teaching-learning process. Hence, the fact which is to be highlighted here, and to be always born in mind, that the learners' involvement is one of the significant facets of tertiary level education in present, especially when the engaged learners would learn more because they take part in various educationally intentional activities (Kuh 2003- cited in Light, Chen, and Ittelson 2012: p.41) built on task-based principles, in particular when asked to develop a learner-based syllabus, which is one of the concerns of this research-paper.

As for the approaches to teaching semantics, the learner-directed ones are considered as ways which best serve the achievement of the goals of both, teachers and learners. Such approaches, in principle, are usually based upon "the principle that learning is totally determined by the nature and will of the students" (Hutchison and Waters 1987- cited in Johns ed. 1999: p.653). The EFL learners, who have passed to the tertiary level (college level) of education, often come to the college-classroom bearing certain styles for approaching learning, and they attend there with "cognitive affective psychological traits that are relatively stable indicators of how learners perceive, interact with, and respond to the learning environment" (Reid 1987: 87- cited in Spolsky ed. 1999: 635). A. Johns argued that many of the learners ....... are fieldindependent, which means "they would prefer to complete their project alone rather than in group" (Johns 1999 -ed. p. 835). Surprisingly, in a learner-led syllabus, tasks could be viewed either as learner actions or as learner representation of tasks. The task, as Doyle (1979) argued, can "focus attention on three aspects of student's work:

(a) The products students are to formulate,

(b) The operations that are to be used to generate the product, i.e., the process, and

(c) The givens, the resources available to students in accomplishing the tasks.

p.637).

(Doyle 1979: p.163- cited in Spolsky 1999:

Furthermore, the performance of tasks, in the teaching-learning environment, can be manifested either by action, or verbally, or written. As assignments and presentations can successively cover the reading and verbal actions, a proposed portfolio or JOURNAL could be considered as a tool of writing action, via which learners can manifest their performance in learning contexts. The JOURNALs are 'high-impact educational practices', especially when they are:

... provided as opportunities in which students can participate both inside

and outside the classroom, these practices allow the students to connect in meaningful ways to course materials, and to transfer knowledge among learning contexts within the academic environment.

(Light, Chen, and Ittelson 2012: p.41)

But, transferring knowledge among learning contexts is not an easy job.

- Why?

- That is, because making connections between learning experiences, such as reading in presumptive references at home and coming to make presentations in the classroom, and then as a return of all that, writing in a JOURNAL at home to develop a learner-led syllabus, is not a job which students, coming to colleges and universities, know how to do. This, no doubt, requires a learner-centered approach tightly connected to a cognitive-code approach, and manifested in a taskbased approach with a JOURNAL as a tool in the core of a series of processes. And all this, in fact, which Dee Fink (2003) referred to exactly as 'significant' learning 
experiences which is needed at the tertiary level of education as an advanced learning.

\section{8 - Definition of Basic Terms}

- Authentic assessment: The extent to which test tasks correspond to language use in non-test situation. (Richard \& Schmidt 2002: p. 42).

- Cognitive-code approach: An approach to Teaching EFL to fostering competence and performance; based on the gestalt assumption that learning must be holistic and accompanied by understanding (Johnson \& Johnson 1999: p. 50).

- Explicit teaching: learning language items by means of overt strategies (Richard \& Schmidt p.192), e.g. performing tasks such as making a presentation in the classroom or writing down what is learnt during the classroom-lesson in a learning JOURNAL.

- Implicit learning: Non-conscious learning (contrasted with explicit teaching), which means learning without awareness of what has been learned (Richard \& Schmidt p. 250).

- Learner-centered teaching: A method of teaching emphasizes the active role of students in learning; by developing patterns of self-directed learning, as well as implying some degree of learner training. (Johnson \& Johnson 1999: pp. 306-7)

- Learning JOURNAL: An on-going account of summarizations and reflections, as outcomes of classroom-study, written down by the students, usually in the form of note-book or electronic mode, "which serves as a source of discussion, reflection or evaluation." (Richards \& Farrell 2012: p.6)

- Learner-led syllabus: A syllabus which takes the direction determined by the learners, and in which it is impossible to predict in advance exactly what route the syllabus will follow. (White 1999 p. 95)

\section{Learning-semantics}

competence: (as speculated by this research-paper) the learners' ability to comprehend the nature, meanings, and dimensions of variables related to 'semantics' as a classroom subject.

- Semantics: The study of MEANING and/in LANGUAGE (Hurford \& Heasley 1996: P. 1; Johnson \& Johnson 1999: p. 286)

- Task-based language-teaching: A teaching approach based on the use of communicative and interactive tasks, which provide an effective basis for learning, based most on negotiation. (Richard \& Schmidt 2002: p. 540).

- Quasi-experimental research: It is a research which does not cover all the variables of the teaching-learning process (Richard \& Schmidt 2002: p. 436), so this research-work mostly cover the effect of a learning JOURNAL as a main variable.

\section{9- Procedures}

As this study is a quasi-experimental one (see sect. 8 above), one of the basic principles of the empirical and experimental approach to education is that the educational decisions are to be informed by evidence obtained by a systematic method from classroom or home, which Haunauer (ed. 2007: p.169) called it attention-based education. In order to achieve the goals of this study, the students' learning-semantics competence (speculated by this study) development was to be questioned and examined. But this, as a matter of fact, could not be made without a process of alignment, on the one hand, between the teaching and learning methods, and on the other hand, between assessment approaches and course learning outcomes, "which is essential for designing activities that engage the learners in an integrated and meaningful way" (Light, Chen, and Ittelson 2012: p.43).

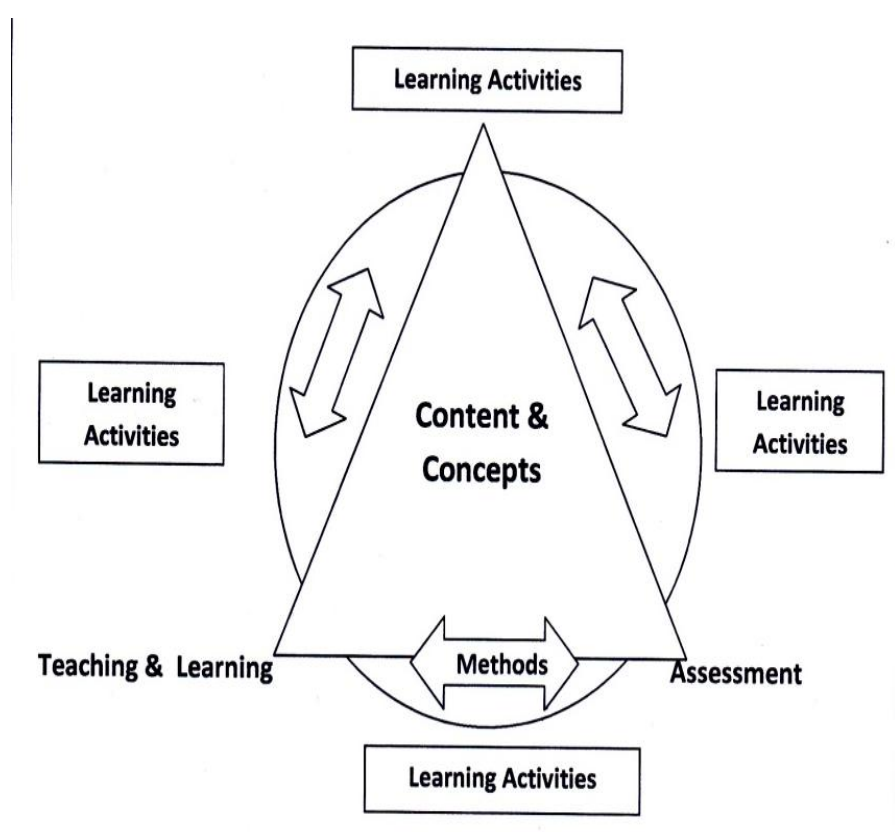

Figure No. 2: Assumed diagram of semantics' teaching-learning process Source/ Adopted from Biggs and Tang (2007); Saroyan \& Amundsen 2004 - cited in Light, Chen, and Ittelson 2012: p. 44

In Figure No.2 above, Biggs and Tang (2007); Saroyan and Amundsen, (2004) showed in a diagram how a portfolio [or a JOURNAL] can document the students learning and their achievements for authentic assessment. As illustrated in the diagram, in the core of the triangle, 'content \& concepts' represent the role of the course-book materials, whereas the 'learning activities', coming from all sides, represent the assumed learners' presentations and JOURNAL, and the methods and assessment are at the base of the triangle.

\section{9 - 1 Quasi-Experimental Design}

9- 1- 1 Community: Sample \& Participants

From among the DoE/SoL/UoZ community, the juniors (3rd-college-stage-students) were selected as a researchsample. The total number of the $3^{\text {rd }}$-year-students 48 , all was taken. They were already divided into two sections (or groups); experimental group (henceforth group A) and control group (henceforth group B), each counted 
24. So, in order to identify the effect of using the presumed JOURNAL, doubtlessly, the same approach of teaching was purposefully used with both groups, except that (group A) learners were asked, to arrange for writing their learning outcomes, of any assignment given to them following a presentations in the classroom, in a JOURNAL to be used as a major reference in study for tests.

\section{9- 1- 2 Program Plan}

A (10-week) experiment was planned and carried out as follows:

* (2 hours/ week 1): The teacher told the learners about choosing them as a community of an experiment, and then explained the plan of the experiment, including the foundation of the 'Semantic \& Pragmatic Group' on facebook-page to circulate information and comments among the research-sample participants as well as the project of the learning JOURNAL as a tool to achieve two presumed objectives:

(1) Achieve progress in study, and

(2) To develop a learner-led syllabus (see the last paragraph of section 7 above) in order to be as a unique reference for their tests whether formative or summative.

Mostly, in point of developing a learningJOURNAL, the students might initially resist the approach of using a JOURNAL considering it as a faddish project; thereby the teacher made it challenging for them to really capitalize on the benefits it might provide, as the experiment went forward (Light, Chen, and Ittelson 2012: p. 69), and then the teacher brought with her a suggested number of books on semantics, as a subject of a classroom, to be put forth for discussion in the classroom, in order to select the ONE to be as a course-book for the experiment.

* (From week 2 until week 9/ 2 hours a week) the learners were given assignments (as tasks), following the steps below for each week:

- In advance, before they came to the $1^{\text {st }}$ lesson/week, the learners were given an assignment to be read in advance at home (one complete entry from the selected (ONE).

During the 1st lesson/week, the learners were stimulated to take part in a seminar about the topic performed by the teacher, and then the students were asked to start discussions, which might enable the teacher to identify how far the learners had comprehended the material. At the end of the lesson the learners then were asked as whole to prepare themselves for presentations (of the same study-entry) performed during the next lesson of the same week.

- During the $2^{\text {nd }}$ lesson/week, according to a fixed time-table, a number of (3-4) learners were asked to make presentations (10 minutes for each) to examine the students readiness and presence as presenters, followed by fruitful discussions. At the end of the lesson the learners were asked to write down (in the class or at home) the outcomes of learning during the said-week in their learning-JOURNALs, and then were given a new task (prepare them to read the next entry of the (ONE) and perform presentations about the related topic for the following week).

At the beginning of every week, the learning JOURNALs were collected weekly, (their materials were analyzed as qualitative data for further quantitative analysis), in order to be authentically assessed and scored as a formative test according to the following qualitative criteria:

1- Technique: understanding the concepts,

2- Habits of the mind: exploring more than one reference,

3- Reflection: comprehending what is required,

4- Craftsmanship: neatness and layout of the JOURNAL, and

5- Effort: completeness of the learning JOURNAL's materials in order to deservedly be the only source in the review for the summative examination.

(Each factor of the above-criteria was given 1/5 of the total (20) marks allotted to the 2nd-semester's formative test).

* (At week 10), a questionnaire was designed and conducted, to be completed by the learners, as a feedback about the experiment they had just taken part in it, and also giving them the opportunity to express orally whatever was missed by the questionnaire.

\section{8- 1-3 Course-book}

In order to select a course-book to be taught during the experiment-time, the following references, shown in Table No.1, were on the classroom's table of discussions:

Table No. 1: Books proposed for a course-book

\begin{tabular}{|l|l|l|}
\hline No. & Book Title & Author(s) \\
\hline $\mathbf{1}$ & $\begin{array}{l}\text { LINGUISTICS } \\
\text { SEMANTICS: } \\
\text { An Introduction }\end{array}$ & John Lyons \\
\hline $\mathbf{2}$ & Semantics & A. P. Cowie \\
\hline $\mathbf{3}$ & $\begin{array}{l}\text { Understanding } \\
\text { SEMANYICS }\end{array}$ & Sebastian Lobner \\
\hline $\mathbf{4}$ & $\begin{array}{l}\text { SEMANTICS: } \\
\text { a course-book }\end{array}$ & $\begin{array}{l}\text { James R. Hurford,\& } \\
\text { Brendan Heasley }\end{array}$ \\
\hline $\mathbf{5}$ & Semantics & John I. Saeed FRMKIN, \\
\hline $\mathbf{6}$ & $\begin{array}{l}\text { AN INTRODUCTION } \\
\text { TO LANGUAGE }\end{array}$ & $\begin{array}{l}\text { Victoria Robert RODMAN, } \\
\text { and Nida HYAMs }\end{array}$ \\
\hline
\end{tabular}

After hot and fruitful discussions, lasting the 2 lessons of week 1 of the experiment, among the students guided by the teacher, showing the pros and cons of this and that, the majority of the students chose A. P. Cowie's Semantics as the ONE; justified and approved by the teacher for it can almost cover the most major entries of 'semantics' as a subject for the classroom, which the semantics-learner needs. Furthermore, all the references listed in (Table No. 1) would also be used as standby references of enhancement when the learners write down, in the learning JOURNAL, the subject-materials' 
outcomes of each week-study, as part of the weeklylearning-task.

\section{9- 1- 4 Learning-JOURNAL Project}

The 10-week-time (25th March to 7th June 2015) allotted for the experiment was exploited as appears in (Table No.2), including the distribution of A.P. Cowie's Semantics entries, as a course-book (c-b for short) for the second semester 2014-2015.

Table No. 2: Assignments' distribution over the 10 weeks of the experiment

\begin{tabular}{|c|c|c|}
\hline No. & $\begin{array}{l}\text { Week } \\
\text { of work }\end{array}$ & $\begin{array}{l}\text { Discussions and entries taught } \\
\text { during the week }\end{array}$ \\
\hline 1 & 1st & $\begin{array}{l}\text { Explaining the experiment and its } \\
\text { objectives/ Discussions about selecting a } \\
\text { course-book for the experiment ( } 2 \text { units) }\end{array}$ \\
\hline 2 & 2nd & $\begin{array}{l}\text { (c-b)Words and meanings (continued): } \\
\text { Words, words, words/Multiple Meanings } \\
\text { (2 units) }\end{array}$ \\
\hline 3 & 3rd & $\begin{array}{l}\text { (c-b) Words and meanings: Meaning } \\
\text { relations/ Set sentences/ Components of } \\
\text { meaning }\end{array}$ \\
\hline 4 & 4th & $\begin{array}{l}\text { (c-b) Word formation: Lexicalization/ } \\
\text { Productivity/ Prefixes/ Suffixes/ } \\
\text { Conversion/ Compounds }\end{array}$ \\
\hline 5 & 5 th & $\begin{array}{l}\text { (c-b) Multiple meaning: Polysemy \& } \\
\text { homonymy/Testing for meanings/ } \\
\text { Specialization of meaning/ metaphor/ } \\
\text { Metonymy/ Creativity \& slang }\end{array}$ \\
\hline 6 & 6th & $\begin{array}{l}\text { (c-b) Meaningful relations: Pairs and } \\
\text { groupings (synonymy) and (ranks)/Binary } \\
\text { contrasts (antonyms),(complementaries) } \\
\text { and(converses/ Groupings (hyponymy) } \\
\text { and (non-branching hierarchies) }\end{array}$ \\
\hline 7 & 7th & $\begin{array}{l}\text { (c-b) Set Phrases: Set phrases and set } \\
\text { sentences/ Collocations/ Idioms/ Proverbs, } \\
\text { catchwords, and formulae }\end{array}$ \\
\hline 8 & 8th & $\begin{array}{l}\text { (c-b) Components of meaning: } \\
\text { Componential analysis/ Marked and } \\
\text { unmarked/ Advantages of componential } \\
\text { analysis/ Denotation and connotation }\end{array}$ \\
\hline 9 & 9th & $\begin{array}{l}\text { (c-b) Semantics and the dictionary: } \\
\text { Grammatical and lexical items/ Complex } \\
\text { word/ Multiple meaning/ meaningful } \\
\text { relations/ Componential analysis/ } \\
\text { Phraseology }\end{array}$ \\
\hline 10 & 10th & $\begin{array}{l}\text { Assessment of the learning-JOURNAL/ } \\
\text { discussions/learners feedback } \\
\text { (questionnaire), preparations for the } \\
\text { summative examination at the end of the } \\
\text { second semester 2014-2015 }\end{array}$ \\
\hline
\end{tabular}

Furthermore, via the interaction with the teacher and the ONE (program-course-book), the performing of presentations in the classroom and writing in the learning JOURNAL at home as learning activities and as outcomes, can be illustrated in (Figure No. 3) below:

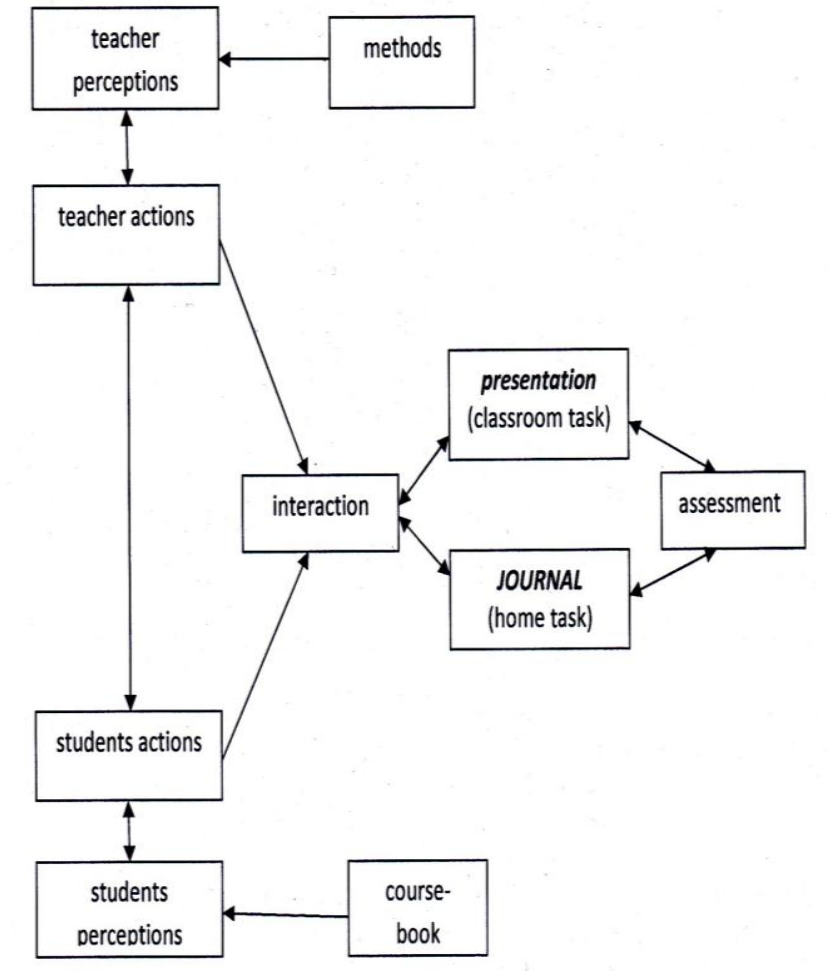

Source: adapted from Branden - ed. : p. 220

Figure No.3: A diagram illustrates the process interaction through which the representations and the JOURNAL comes as outcomes of interaction between the pedagogue and learners.

Perceiving the components of the diagram above as a complete process, which in both, the teacher's cognition and action, are not isolated from each other, but presented as interactive ones to inspire action, in and outside classroom, in order to feed the learners' perceptions, as the teacher works from lesson to lesson (Breen et al., 2001; Fang, 1996 -cited in Branden ed.:p.219). In addition, the teacher's actions and perceptions not only impacted each other, but also influenced, and were influenced by, the learners' actions and perceptions. Thus, Interaction is seen as a major factor in the complex interplay of the situation, which involves a multiple-task-based work weekly for the learners as follows:

- As an introductory task, prior reading of the topic at home, trying to get information and make sense of the topic-text, as an assignment before attending the lecturing of the lesson,

- Discussing the most prominent concepts of the lesson with the teacher and classmates during the lecture in the classroom ( $1^{\text {st }}$ lesson/weekly),

- Priority preparation of the assignment at home, for presentation,

- Making presentation in the classroom and taking part in the discussions ( $2^{\text {nd }}$ lesson weekly), and

- Writing down their reflections in the learningJOURNAL (at school or at home) as an outcome from the experience they passed through the said-week. 
9. 1. 5 Objectives of each Lesson in the course of the experiment:

\section{1.5. 1 General:}

- Recognize the areas where semantics work, as being one of the main-stream of theoretical linguistics,

- Identify the concepts of meaning in language at all levels (word, phrase, and sentence), especially on part of the actual use of language,

- Identify semantic relations, and

- Practice semantic analysis.

\section{9- 1- 5- 2 Specific:}

\section{Developing a Learner-led Syllabus}

-Does speculating a learning-ability like the 'learning-semantics competence' have to do with a question about the sort of syllabus which is needed to elicit concepts related to semantics and make them more comprehendible?

The answer is:

-Presumptively, yes .

In his The ELT Curriculum (1999), Ronald V. White differentiated between two types of syllabus:

-Type A, which is notional-functional, and it is the most recent type of content-based syllabus, and

-Type B, which is a methods-based syllabus.

For further details about the two types of syllabus see the diagram below:

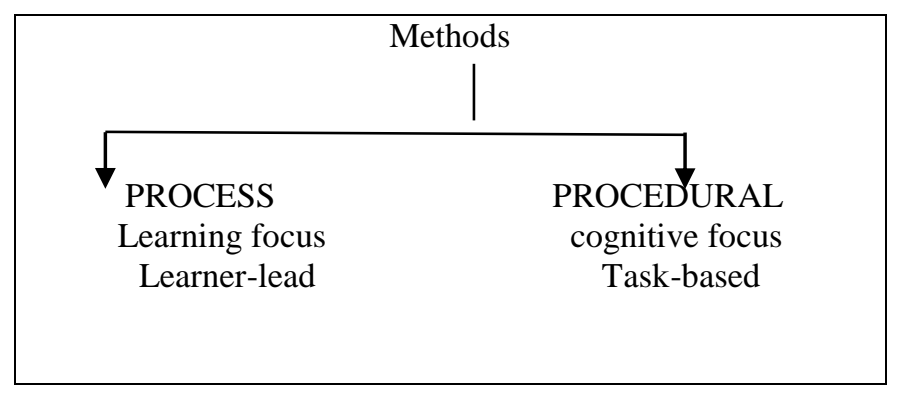

Figure No.4: Diagram of methods-based syllabuses (Adapted from White 1999)

According to White, Type A syllabus is a radical one, because it includes building the syllabus on methodology, where tasks rather than content form the focus (White 1999 p. 95). But, on the other hand, White explained that such a syllabus if it is PROCEDURAL, it would stay a teacher-led one, since the teacher is in control of the task, whether in choosing the tasks or in organizing them. So, by contrast, he argued that a learner-led syllabus would take a direction decided by the learner. Furthermore, he compared the process of developing such a learner-led syllabus to the process of building a house a section at a time, which should be negotiated among the builders (the learners). This is exactly the syllabus type which he called the PROCESS type, which is advocated by Breen \& Candlin (Ibid p. 95), and its rationale is an educational one rather than a linguistic one (Candlin 1987 and Breen 1984: 86- cited in White 1999 p. 97). But, finally, a learner-led syllabus does not mean that the teacher will be completely under the mercy of the learners.

Finally, this study presumes the learning JOURNAL as one which stands for the PROCESS type of syllabus which eventually may lead to developing a learner-led syllabus in the course of this study's experiment, i.e., in a process like that of building a house a section at a time as said before..

\section{9- 1- 6 Assessment Instruments}

To judge the pitfalls and payoffs of the experiment, it first needed to specify the type and nature of the instruments to be adopted for assessment, as well as specifying the variables to be examined:

- As a formative test during the 10-week-program, an average of scale (out of 20) was adopted for both groups (A) and (B), except that using the learning JOURNAL as basis of evaluation for group (A) according to the afore-mentioned qualitative criteria in (9-1-2), while for group (B) the results' average of an ordinary semester-test was the basis for evaluation.

- The results of the 2014-2015 academic-year's final examination, were taken as a summative examination results, and were adopted as the program-end examination for evaluating both groups (A) and (B) achievements, according to the college's formal scale (out of 60), but for group (A) according to the qualitative criteria mentioned in (9-1-2) above.

Furthermore, in order to fulfill the framework of an authentic assessment, it was very necessary also to ask the participants to fill out a feedback questionnaire form (see Appendix No.2) which included items about the development of the students' motivations and goals for learning 'semantics', to be a subject of a quantitative analysis. Naturally, the questionnaire form was exposed to a jury (see their names in Appendix No.1) in order to check its items adequacy.

\section{0- Data: Collection and Analysis}

The data obtained for this study were technically analyzed as follows:

\section{0-1 Equivalence Pre-test}

To start the experiment, a pre-test was conducted to find out if the research-sample's 2 groups have the same value or not.

Table No. 3: Pre-test results

\begin{tabular}{|l|l|l|l|l|l|}
\hline Group & No. & Mean & Sd. & t-value & Sig. \\
\hline A & 24 & 11.416 & 3.586 & 0.506 & NS \\
\cline { 1 - 4 } B & 24 & 11.958 & 3.827 & & \\
\hline
\end{tabular}

The results of the pre-test in Table No 3 showed no significant differences between the two groups (A) and (B), which denote that they had the same value for the purpose of the study. 


\section{0-2 Discussion and Analysis of Data}

1- The first hypothesis denotes that "Using a learning-JOURNAL, on part of group (A), in teaching-learning semantics, no significant differences would be expected in the formative test results between group (A) and group (B) achievements."

Using the ANOVA system of analysis indicated significant differences in Group (A) achievements, manifested statistically in the marks of the students' during the 8-week study of semantics; illustrated in the following table:

Table No. 4: ANOVA

VAR00002

\begin{tabular}{|l|l|l|l|l|l|}
\hline & $\begin{array}{l}\text { Sum of } \\
\text { squares }\end{array}$ & df & $\begin{array}{l}\text { Mean } \\
\text { square }\end{array}$ & F & Sig \\
\hline Between & 659.813 & 7 & 94.259 & 12.63 & \\
$\begin{array}{l}\text { groups } \\
\text { Within } \\
\text { groups } \\
\text { Total }\end{array}$ & 1373.167 & 184 & 7.463 & 0 & 0.05 \\
\hline
\end{tabular}

In order to identify the details of the students' development in achievement, the means of the students' marks during 8 weeks were dealt with as in the Table No. 4 below:

Table No. 4: Statistical differences between Group (A) and Group (B) in the formative test

\begin{tabular}{|l|l|l|l|l|l|}
\hline Group & No. & Mean & Sd. & t-value & Sig. \\
\cline { 1 - 4 } A & 24 & 11.212 & 1.353 & 0.682 & NS \\
\cline { 1 - 4 } & 24 & 10.538 & 4.312 & & \\
\hline
\end{tabular}

In Table No.4, no significant differences could be seen between the achievements of groups (A) \& (B) in the formative test.

Hence, the first hypothesis is proved and accepted.

2- The second hypothesis states that: "Using a learning JOURNAL, on part of group (A), in teaching-learning semantics, significant differences are expected as a gradual weekly development in group (A)'s achievements."

Table No5: Development in group (A) achievements

\begin{tabular}{|l|l|l|l|}
\hline week & N & Mean & $\begin{array}{l}\text { Std. } \\
\text { Deviation }\end{array}$ \\
\hline $\mathbf{1 . 0 0}$ & 24 & 8.7917 & 2.55341 \\
$\mathbf{2 . 0 0}$ & 24 & 9.0417 & 3.02855 \\
$\mathbf{3 . 0 0}$ & 24 & 9.5000 & 2.53669 \\
$\mathbf{4 . 0 0}$ & 24 & 11.0417 & 1.80529 \\
$\mathbf{5 . 0 0}$ & 24 & 11.7083 & 2.13621 \\
$\mathbf{6 . 0 0}$ & 24 & 12.5000 & 3.48911 \\
$\mathbf{7 . 0 0}$ & 24 & 13.5833 & 3.24261 \\
$\mathbf{8 . 0 0}$ & 24 & 13.7500 & 2.65805 \\
\hline Total & $\mathbf{1 9 2}$ & $\mathbf{1 1 . 2 3 9 6}$ & $\mathbf{3 . 2 6 2 4 9}$ \\
\hline
\end{tabular}

In Table No.5, significant differences are seen as an increase in group (A) learners' achievements rising gradually, in mean, from (8.7917) up to (13.2396) during the period of 8 -week-study.

Hence, the second hypothesis is proved and accepted.

3- The third hypothesis denotes that "Using a learning JOURNAL, on part of group (A), in teaching semantics, no significant differences would be expected between group (A) and Group (B) achievements in the summative tests."

Table No. 6: Statistical differences between Group (A) and Group (B) in the summative test

\begin{tabular}{|l|l|l|l|l|l|}
\hline Group & No. & Mean & Sd. & t-value & Sig. \\
\cline { 1 - 4 } B & 24 & 42.625 & 6.863 & 2.142 & 0.05 \\
\hline
\end{tabular}

In Table No.6, a significant difference could be seen at (0.05) between groups (A) \& (B) achievements, manifested in mean. For Group (A) it reads (42.625), while for Group (B) it reads (37.291), which indicated a large difference between the results of the two groups, in favor of group A.

Hence, the third hypothesis has been nullified.

4- The fourth hypothesis states that "The students of semantics have the ability to develop a learnerled syllabus, based on materials written in a learning JOURNAL to use it as a unique reference to improve their achievements in both, the formative-test and the summative-test." 
JUHD / Vol. 3, No. 2, june 2017: pp 841-854

e-ISSN: 2411-7757, p-ISSN 2411-7765

Table No. 7

Descriptive findings of the Learners feedback about the Learning

JOURNAL

\begin{tabular}{|c|c|c|c|c|}
\hline Variance & No. & Minimum & Maximum & Mean \\
\hline VAR00001 & 24 & 3.00 & 5.00 & 4.0417 \\
\hline VAR00002 & 24 & 1.00 & 4.00 & 2.4583 \\
\hline VAR00003 & 24 & 3.00 & 5.00 & 3.5000 \\
\hline VAR00004 & 24 & 2.00 & 3.00 & $2.7083-$ \\
\hline VAR00005 & 24 & 3.00 & 5.00 & 3.8333 \\
\hline VAR00006 & 24 & 3.00 & 5.00 & 3.5417 \\
\hline VAR00007 & 24 & 1.00 & 3.00 & 2.2917 \\
\hline VAR00008 & 24 & 3.00 & 4.00 & 3.2500 \\
\hline VAR00009 & 24 & 3.00 & 5.00 & 3.8333 \\
\hline VAR000010 & 24 & 3.00 & 4.00 & 3.1667 \\
\hline VAR000011 & 24 & 1.00 & 4.00 & 2.0000 \\
\hline VAR000012 & 24 & 3.00 & 5.00 & $4.0417-$ \\
\hline VAR000013 & 24 & 2.00 & 4.00 & 3.0833 \\
\hline VAR000014 & 24 & 3.00 & 5.00 & 3.7500 \\
\hline VAR000015 & 24 & 2.00 & 3.00 & 2.5000 \\
\hline VAR000016 & 24 & 3.00 & 5.00 & 3.8333 \\
\hline VAR000017 & 24 & 3.00 & 4.00 & 3.2500 \\
\hline VAR000018 & 24 & 3.00 & 5.00 & 4.0833 \\
\hline VAR000019 & 24 & 1.00 & 3.00 & $2.0417-$ \\
\hline VAR000020 & 24 & 3.00 & 5.00 & 3.4167 \\
\hline VAR000021 & 24 & 1.00 & 3.00 & 1.9583 \\
\hline Valid N (listwise) & 24 & & & \\
\hline
\end{tabular}

Table No.8: Ranking of the questionnaire statements in value

from highest to lowest

\begin{tabular}{|l|l|l|l|l|l|l|}
\hline $\begin{array}{l}\text { Stateme } \\
\text { nt No. }\end{array}$ & $\begin{array}{l}\text { Mea } \\
\mathbf{n}\end{array}$ & $\begin{array}{l}\text { Ran } \\
\mathbf{k}\end{array}$ & $\begin{array}{l}\text { Stateme } \\
\text { nt No. }\end{array}$ & $\begin{array}{l}\text { Mea } \\
\mathbf{n}\end{array}$ & $\begin{array}{l}\text { Ran } \\
\mathbf{k}\end{array}$ \\
\hline 18 & 4.083 & $1^{\text {st }}$ & 13 & 3.083 & $10^{\text {th }}$ \\
1 and 12 & 3 & $2^{\text {nd }}$ & 4 & 3 & $11^{\text {th }}$ \\
5,9, and & 4.041 & $3^{\text {rd }}$ & 15 & 2.708 & $12^{\text {th }}$ \\
16 & 7 & $4^{\text {th }}$ & 2 & 3 & $13^{\text {th }}$ \\
14 & 3.833 & $5^{\text {th }}$ & 7 & 2.500 & $14^{\text {th }}$ \\
6 & 3 & $6^{\text {th }}$ & 19 & 0 & $15^{\text {th }}$ \\
3 & 3.750 & $7^{\text {th }}$ & 11 & 2.458 & $16^{\text {th }}$ \\
20 & 0 & $8^{\text {th }}$ & 21 & 3 & $17^{\text {th }}$ \\
17 & 3.541 & $9^{\text {th }}$ & & 2.291 & \\
10 & 7 & & & 7 & \\
& 3.500 & & & 2.041 & \\
& 0 & & & 7 & \\
& 3.416 & & & 2.000 & \\
& 7 & & & 0 & \\
& 3.250 & & & 1.958 & \\
& 0 & & & 3 & \\
& 3.166 & & & & \\
& 7 & & & & \\
\hline
\end{tabular}

In Table No.8 above, the findings of the questionnaire indicate that:

(Statement 18) which denotes "The L-J was to me of a great help as a reference in examinations" came as the first in rank among the learners' interest with a mean of (4.0833)

- (Statements 1 and 12) which successively states "The L-J guided me to improve my writing Ststillseviationd "The L-J increased my self.75060tence in interacting with my teacher and .770@izmates." came next in the students interests .720132means of (4.0417) for both.

4(64attements 5, 9, and 16) which successively .5tetfortes "The L-J enlightened me about the role .58823 3emantics in the linguistic-study contexts.", .44DR3 L-J stimulated me to improve my .55000 vement in research-work" and "The L-J $.564156 d$ me to differentiate between the meanings .380600 ords at different levels." came in the third .65 18 8with means of (3.8333).

$5(50$ 06ement 6) which states "The L-J provided .49825 vith innovative ways of learning." came in .5 Bid fifth rank with a mean of (3.5417).

5 (Btatement 3) which denotes "The L-J helped .48454 to make use of dictionaries and other .4403portive study sources." came in the sixth 1 19hkasith a mean of (3.5000).

6840tment 20) which denotes "The L-J enabled 58259 o develop my writings in lessons other than .5003 semantic-lesson." came seventhly with a mean of (3.4176).

(Statement 17) which states "The L-J taught me how to make briefs of other study-subjects' course-books." came eighth with a mean of (3.2500).

- (Statement 10) which states "The L-J stimulated me to systemize my performance in other studysubjects." came ninth with a mean of (3.1667)

- (Statement 13) which denotes that the L-J stimulated the learners to make further readings on the topics of semantics; came tenth with a mean of (3.0833).

- (Statements 4, 15, 2, 7, 19, 11, and 21) successively came $11^{\text {th }}, 12^{\text {th }}, 13^{\text {th }}, 14^{\text {th }}, 15^{\text {th }}, 16^{\text {th }}$, and $17^{\text {th }}$.

Significantly, the statement ranking from $1^{\text {st }}$ to $10^{\text {th }}$ all, in nature, stimulate the learner to take the initiative to do something, and not to mention the effect of the other statement in the same respect.

Hence, the fourth hypothesis is proved and accepted pursuant to the feedback of the learners. 


\section{1-Conclusions and Recommendations}

\section{1-1 Conclusions}

In the light of the results of data analysis and discussion, the following conclusions could be arrived at:

1- Using learning JOURNAL as an approach in teaching semantics has positive effects on the learners' creative ability in achievement (Hypotheses 1, 2, and 3).

2- Using a cognitive-based and task-based as a mixed-approach in teaching semantics can stimulates the learners to develop a learner-led syllabus to be as a major source in gettingready-review for various types of tests (Hypothesis 3).

3- Using learning JOURNAL generally in teaching, if it were, can improve the learners' compositional skills to make significant progress research (Hypothesis 4 and the questionnaire results).

4- Using learning JOURNAL as a writing activity of assignments given to the learners enables the learners to develop an assumed learner-led course-book to use it as a major reference in tests (hypothesis 4).

\section{1-2 Recommendations}

In the view of the above-drawn findings, the following recommendations could be justifiably sounding:

1- Proving its reliability by this research work, teachers of subjects other than semantics can use the learning JOURNAL as a creative tool in the teaching-learning process.

2- Researchers can dig in more details and more deeply in the usefulness of using a learning JOURNAL in teaching semantics, especially in expanding the experiment to investigate the learners' ability to comprehend variables of the semantics subject other than major entries of semantics.

\section{References}

- Adamson H. D. (2009) Interlanguage Variation in Theoretical and Pedagogical Perspective. UK

Routledge

- Aiian, K. (1986) LINGUISTICS MEANING 2 Volumes. London \& New York Routledge \& Kegan Paul

- Branden, K. Van den (2006) Task-based Language Education: From theory to practice. UK Cambridge University Press

- Campbell, J. K. \& Share, O 'Pourke D. (2002) Meaning and Truth. New York Seven Bridge Press

- Chappelen, H. \& Lepore, E. (2007) Language Turned on Itself. New York Cambridge University Press

- Cook, V. (2008) Second Language Learning and Teaching. London Hodder Education

- Cowie A. P. (2009) Semantics UK Oxford University Press

- Cruse, A. (2006) A Glossary of Semantics and Pragmatics. UK Edinburgh University press Ltd.

- Fromkin, V. \& Rodman, R. \& Hyams, N. (2003) AN INTRODUCTION TO LANGUAGE. USA THOMSON

- Geeraerts, D. (2010) Theories of Lexical Semantics. UK Oxford University Press.

- Goddard, C. (2007) Semantic Analysis: A Practical Introduction UK Oxford University Press

- Griffiths, P. (2006) An Introduction to English Semantics and Pragmatics. UK Edinburgh University Press

- Harmer, J. (2012) The Practice of English language

Teaching. Pearson/ Longman UK

- Hedge, T. (2003) Teaching and Learning in the Language Classroom. Oxford Oxford University Press

- Hughes, A. (2003) Testing for Language Teachers. UK Cambridge University Press

- Hurford, J. \& Heasley, B. (1996) SEMANTICS: a Course-book. USA Cambridge University Press

- Lyons, John (1996) LINGUISTICS SEMANTICS: An Introduction. USA/ Australia Cambridge University Press

- Johnson, K. \& Johnson, H. (1996) Encyclopedic Dictionary of APPLIED LINGUISTICS. UK/USA Blackwell Publishers

- Kearns, Kate (2011) Semantics. UK Macmillan.

- Kumaravadivelu, B (2012) Language Teacher Education for Global Society. USA/UK Routledge

- Light, T. P. \& Chen, H. L. \& Ittelson, J. C. (2012) Documenting Learning with ePortfolios USA JOSSEYBASS

- Lobner, S. (2002) Understanding Semantics London - LoCastro, V. (2012) Pragmatic for Language Educators New York/ UK Routledge

- Mathews, P. H. (2007) Oxford Concise Dictionary of Linguistics. Oxford Oxford University Press

- Nunan, D. \& Bailey, K. I. (2009) Exploring Second Language Classroom Research. Canada HEINILE

- Richard, C. J. \& Schmidt, R. (2002) Dictionary of Language teaching \& Applied Linguistics. London Longman 
JUHD / Vol. 3, No. 2, june 2017: pp 841-854

e-ISSN: 2411-7757, p-ISSN 2411-7765

- Richards, J. C. \& Farrell, T. S. (2012) Professional Development for Language Teachers UK Cambridge

University Press

- Rose, K. \& Kasper, G. (2001) Pragmatics in

Language Teaching. Cambridge. UK

- Reynolds, C. R. \& Livingston, R. B. \& Willson, V. (2005) Measurement and Assessment in Education USA Pearson Education

- Scrivener, J. (2012) Learning Teaching. UK

Macmillan Books

- Senior, R. M. (2006) The Experience of Language

Teaching. UK Cambridge University Press

- Spolsky, B. \& Hult, F. M. (ed-2008) The Handbook of

Educational Linguistics. USA/Australia Blackwell

Publishing

- Spolsky, B. (ed-1999) Concise Encyclopedia of

Educational Linguistics. Oxford. UK Elesevier Science

Ltd.

- Ungerer, F. \& Schmid, H-J. (2006) AN

INTRODUCTION TO COGNITIVE LINGUISTICS UK

Pearson-Longman
- Van den Brandon, Kris (ed-2006) Task-Based Education. USA/UK Cambridge University Press

- Widdowson, H. G. (2003) Defining Issues in Language Teaching. Oxford USA Oxford University

- White, V. R. (1999) The ELT Curriculum: Design, Innovation and Management. Oxford UK \& Cambridge USA BLACKWELL

\section{Appendix No. 1}

Names of the jury who examined the questionnaire statements' adequacy:

1- Dr. Hussein Ali Gargari (Prof.)/ College of Languages/ Nawroz University

2- Dr. Chachaan Jum'ah Mohammed (Assist Prof.)/Department of Psychological \& Educational Sciences /Faculty of Basic education/University of Duhok

3- Dr. Sami Abdul-Aziz Al-Ma'mouri (Prof.)/Department of English/College of Basic Education/ University of Diyala.

4-Mr.Ahmed Khalis Shalan (lecturer)/ College of Languages/ Nawroz University

\section{Appendix No. 2}

\section{Questionnaire}

Dear student'

The researchers are carrying out a study entitled "The Effect of Using the learning-JOURNA, in Teaching Semantics, on the Tertiary Level Juniors' Achievements "

You, being a research-sample's member of the said-study, I have the pleasure to benefit from your frank and clear answers to the items of the following questionnaire, as a feedback about the usefulness of the learningJOURNAL as a learning tool.

Thank you for being helpful.

\section{Researcher}

\section{Ghyda Ali Muhammed}

University of Zakho

\begin{tabular}{|l|l|}
\hline College: & University: \\
\hline Stage: & Department: \\
\hline Gender: & Age: \\
\hline
\end{tabular}

Note: Dear students, on ticking the square opposite to the items below, bear in mind that the abbreviation (L-J) in the said items stands for the (learning-JOURNAL) used in the teaching-learning process of semantics you experienced during the second semester of the academic-year. 


\begin{tabular}{|c|c|c|c|c|c|c|}
\hline No. & Items & Always & Often & Sometimes & Rarely & Never \\
\hline 1 & $\begin{array}{l}\text { The L-J guided me to improve my writing } \\
\text { skills. }\end{array}$ & & & & & \\
\hline 2 & $\begin{array}{l}\text { The L-J did not help me to make better } \\
\text { understanding of the semantic components. }\end{array}$ & & & & & \\
\hline 3 & $\begin{array}{l}\text { The L-J helped me to make use of } \\
\begin{array}{l}\text { dictionaries } \\
\text { and } \\
\text { sources }\end{array}\end{array}$ & & & & & \\
\hline 4 & $\begin{array}{l}\text { The L-J did not offer to me the chance to } \\
\text { arrange my study-schedule }\end{array}$ & & & & & \\
\hline 5 & $\begin{array}{l}\text { The L-J enlightened me about the role of } \\
\text { semantics in the linguistic-study contexts. }\end{array}$ & & & & & \\
\hline 6 & $\begin{array}{l}\text { The L-J provided me with innovative ways of } \\
\text { learning. }\end{array}$ & & & & & \\
\hline 7 & $\begin{array}{l}\text { The L-J did not motivate me enough to take } \\
\text { the responsibility of my learning. }\end{array}$ & & & & & \\
\hline 8 & $\begin{array}{l}\text { The L-J provided me with better } \\
\text { understanding of both teacher's and learner's } \\
\text { role in the teaching-learning process }\end{array}$ & & & & & \\
\hline 9 & $\begin{array}{l}\text { The L-J stimulated me to improve my } \\
\text { achievement in research-work. }\end{array}$ & & & & & \\
\hline 10 & $\begin{array}{l}\text { The L-J stimulated me to systemize my } \\
\text { performance in other study-subjects. }\end{array}$ & & & & & \\
\hline 11 & $\begin{array}{l}\text { The L-J did not guide me to make semantic } \\
\text { analysis. }\end{array}$ & & & & & \\
\hline 12 & $\begin{array}{l}\text { The L-J increased my self-confidence in } \\
\text { interacting with my teacher and classmates. }\end{array}$ & & & & & \\
\hline 13 & $\begin{array}{l}\text { The L-J did not stimulate me to make further } \\
\text { readings on the topics of semantics. }\end{array}$ & & & & & \\
\hline 14 & $\begin{array}{l}\text { The L-J taught me how to be self-dependent } \\
\text { in learning. }\end{array}$ & & & & & \\
\hline 15 & $\begin{array}{l}\text { The L-J did not show me a way to understand } \\
\text { the meaning relations. }\end{array}$ & & & & & \\
\hline 16 & $\begin{array}{l}\text { The L-J helped me to differentiate between } \\
\text { the meanings of words at different levels. }\end{array}$ & & & & & \\
\hline 17 & $\begin{array}{l}\text { The L-J taught me how to make briefs of } \\
\text { other study-subjects' course-books }\end{array}$ & & & & & \\
\hline 18 & $\begin{array}{l}\text { The L-J was to me of a great help as a } \\
\text { reference in examinations }\end{array}$ & & & & & \\
\hline 19 & $\begin{array}{l}\text { The L-J did not teach me how to make an } \\
\text { outline of the study-items. }\end{array}$ & & & & & \\
\hline 20 & $\begin{array}{l}\text { The L-J enabled me to develop my writings } \\
\text { in lessons other than the semantic-lesson. }\end{array}$ & & & & & \\
\hline 21 & $\begin{array}{l}\text { The L-J did not guide me to systemize my } \\
\text { answers in the examinations. }\end{array}$ & & & & & \\
\hline
\end{tabular}

